\title{
Correction to: Non-destructive Testing of a Monocrystalline Silicon Solar Cell: Magnetic Field - Electrical Properties Correlation
}

\section{A. Ibrahim ${ }^{1}$}

Published online: 1 February 2019

(C) Springer Nature B.V. 2019

\section{Correction to: Silicon}

$$
\text { https://doi.org/10.1007/s12633-017-9695-x }
$$

Due to an oversight, the author incorrectly labeled the axis in Fig. 5 of the published online version. The correct Fig. 5 is shown below.

Fig. 5 Dark current and voltage with magnetic field for $\mathrm{a}^{+} \mathrm{pp}^{+} \mathrm{Si}$ solar cell of area $1.8 \mathrm{~cm}^{2}$ in reverse direction

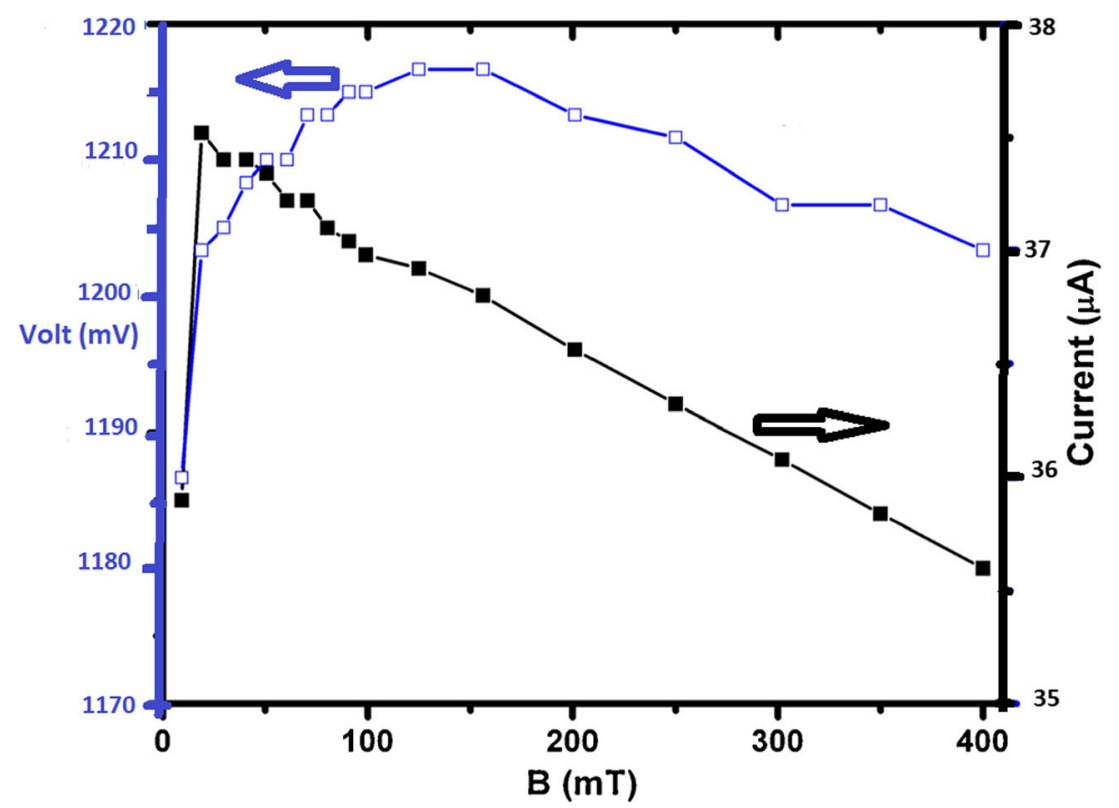

Publisher's Note Springer Nature remains neutral with regard to jurisdictional claims in published maps and institutional affiliations.

The online version of the original article can be found at https://oi.org/ 10.1007/s12633-017-9695-x

\footnotetext{
A. Ibrahim

ali_02us@yahoo.com

1 Physics department, Faculty of Science, Tanta University,

31527 Tanta, Egypt
} 